tina's third largest port, on June 24 and arrived in Cape Town, South Africa, on September 17 after a three-months' scientific cruise. Her arrival at the South African port completed the first half of the Winter Weddell Sea Project coordinated by the Alfred Wegener Institute of Bremerhaven, West Germany. The Weddell Sea is a three million square miles $(7,770,000 \mathrm{sq} . \mathrm{km})$ embayment of the coast of Antarctica lying south-east of the tip of South America.

In addition to 14 American research workers aboard the ship, there were 36 other oceanographers, ice physicists, meteorologists, and marine biologists, from West Germany, Great Britain, Austria, Switzerland, and Argentina. Although the distance from the ice-edge to the coast of the continent is about 800 miles $(1,280 \mathrm{~km})$, the ship had travelled 3,400 miles $(5,400 \mathrm{~km})$ on a zigzagging course to collect samples and make oceanographic measurements.

The Expedition is now on its second phase, focusing on bottom-water formation and research into biological development on the coastal shelf of the eastern Weddell Sea in early spring.

RALPH KAZARIAN
National Science Foundation
1800 G Street
Washington
DC 20550, USA.

RALPH KaZARIAN $1800 \mathrm{G}$ Street

DC 20550, USA.

\title{
Slovak Union for Nature and Landscape Protection
}

This association, with the acronym SZOPK (Slovensky zväz ochrancov prirody a krajiny), was founded in 1969 as a voluntary, special-interest organization. It is an association of individuals, organizations, and institutions, of the Slovak Socialist Republic, concerned with Nature and landscape protection.

The main aims of the Slovak Union for Nature and Landscape Protection are:

- to participate effectively in the protection of natural resources and landscape and in the preservation of the quality of the environment,

- to introduce Nature and landscape and the regularities of their development to the widest possible masses of human population and their education towards cultivated relationship to Nature,

- to bring its members to understand Nature and landscape, to educate them specially and win them for creative activity in the care of Nature and landscape,

- to promote the natural beauty and natural resources of the Slovak Socialist Republic,

- to help to keep the legal precepts regulating Man's intervention in Nature and landscape, and

- to develop initiative for intensifying Nature protection and landscape creation.

The activity of the Slovak Union for Nature and Landscape Protection is directed by the central committee and district committees, the executive bodies being basic organizations and hobby-groups; special and consultational services are provided by sections and commissions. The development of the Union falls within the competence of the Ministry of Culture of the Slovak Socialist Republic, which directs the activity of the Union professionally and methodically.

In the year 1985 the Slovak Union for Nature and Landscape Protection had 14,000 individual members in 260 basic organizations and 438 collective members with over 313,000 employees, 11 special commissions, and 612 hob- by-groups of young protectors of Nature with almost 11,000 children up to the age of 15 years.

For its members the Union provides:

- Publication of an illustrated journal, Poznai a chrán ('Learn and Protect'), of 204 printed pages in extent annually;

- Publication of methodological handbooks, materials from conferences and seminars, posters, leaflets, and propagational materials;

- Organization of interdepartmental sessions and press conferences;

- Organization of summer camps (TOP), excursions, courses of instruction, and training for members and functionaries;

- Realization of expositions, competitive-amusing and instructive-educational undertakings for the public in cooperation with cultural and educational bodies and social organizations-especially with the Socialist Union of Youth and mass-media;

- In cooperation with the state protection of Nature's protectional and regulational interventions, information and guarding service, inventorization and documentation of protected and other significant parts of Nature, cultural-historical and technical monuments and their background;

- Design, arrangement, and operation, of instructive paths and instructive localities; and

- Development of cooperation and exchange of information with partner organizations in Czechoslovakia, socialist, and other countries.

Many instructive-educational and propagational undertakings are also organized by the Union for the wider public.
JÁN KLEINERT
Klokoćova 7
CS-974 01 Banská Bystrica Czechoslovakia.

\section{Declaration: Ecoforum For Peace}

We, research workers who share ecological concern and who meet to participate in the International Conference on Protection of the Environment and the Defence of World Peace, held in Varna, Bulgaria, during 25-28 August 1986*:

- Considering that a nuclear war would bring devastation to the ecological systems of the planet;

-Recognizing that, even without war, the development, testing, production, and deployment, of nuclear weapons,

\footnotetext{
* See the account by Carol E. Westing published on pages 373-4 of this issue. - Ed.
}

and of other weapons of mass destruction, is accelerating ecological disasters for Humankind;

- Believing that, because of their global dimensions, our ecological problems demand new dimensions of cooperation among all peoples and states, and that this free collaboration is not compatible with military preparations;

- Realizing that human intrusions into the environment through various aspects of modern technology pose grave threats if not undertaken from an ecological perspective; and

- Aware that true international security depends upon the achievement of harmony between Humankind and Nature: 